Diabetologia 9, 400-402 (1973)

(C) by Springer-Verlag 1973

\title{
Hyperglucagonemia of the Isolated Perfused Pancreas of Diabetic Mice ( $\mathrm{db} / \mathrm{db})$
}

\author{
H. Laube*, R.D. Fussgänger, V. Maier, and E. F. Pfeiffer \\ Department of Endocrinology and Metabolism, Centre of Internal Medicine and Pediatrics. University of Ulm/D., \\ Germany
}

Received: March 12, 1973, in revised form: May, 28, 1973

\begin{abstract}
Summary. Diabetes mellitus is held to be accompanied. by inappropriately high levels of plasma glucagon relative to blood glucose concentrations. This has been interpreted as indicating lack of insulin. To establish glucagon release in presence of high levels of endogenous insulin, the effects of both glucose and arginine were studied in the isolated perfused pancreas of genetically diabetic mice $(\mathrm{db} / \mathrm{db})$. Stimulation with glucose $2.75 \mathrm{mM}$ or glucose plus arginine $8.25 \mathrm{mM}$ exhibited a pronounced hyperglucagon-
\end{abstract}

Patients with inherited diabetes mellitus are said to demonstrate increased pancreatic glucagon release relative to blood sugar levels [25, 16]. Extremely high levels of glucagon have also been reported in alloxan treated dogs [17], streptozotocin diabetic rats [13] and in patients with severe ketoacidosis [1]. This has been interpreted as a state of decreased suppressibility of the alpha cell in the diabetics, probably on the base of lack of insulin. Infusion of insulin in animals with artificially achieved diabetes corrected instantly the state of hyperglucagonemia.

Recent studies in diabetic patients, however, exhibited only a slow and modest decline of glucagon after infusion of high insulin dosages. It was, therefore, concluded that mere lack of insulin may not adequately explain the alpha cell abnormality in diabetes mellitus [26]. Most of these patients, however, were receiving tolbutamide, and exhibited a markedly decreased insulin release following a carbohydrate meal compared to non diabetic controls.

The present report deals with the alpha cell function in diabetic mice. The isolated perfused mouse pancreas was examined. Due to the hyperinsulinism in these obese animals the effect of high endogenous insulin release on pancreatic glucagon secretion was examined.

\section{Material and Methods}

For the present experiments diabetic mutant mice (C $57 \mathrm{BL} / \mathrm{Ks}-\mathrm{db} / \mathrm{db}$; Jackson Laboratory, Bar Harbour, Maine, USA), weighing $50-60 \mathrm{~g}$, approximately $2-3$ months old, and lean litter controls were used. Each group consisted of 5 animals.

The mice were operated on after a $6 \mathrm{~h}$ fast. The pancreas was dissected under sodium pentobarbital anesthesia in a way similar to that already described for rats [23]. Arterial flow was achieved by cannulation

* Supported by Deutsche Forschungsgemeinschaft, Bad Godesberg. emia. Following glucose $8.25 \mathrm{mM}$, however, there was no depression of glucagon secretion. Despite excessive high levels of endogenous insulin, there was a pattern of rather non-suppressible glucagon release. Lack of insulin per se, therefore, is unlikely to be the sole cause of hyperglucagonemia in this type of genetic animal diabetes mellitus.

Key words: Diabetic mice, isolated perfused pancreas, high insulin levels, hyperglucagonemia. of the thoracic aorta. The perfusion medium consisted. of an Umbreit buffer supplemented with 1\% albumin (Fa. Behring Werke, Marburg) and equilibrated with $95 \% \mathrm{O}_{2}: 5 \% \mathrm{CO}_{2}$. The FFA content of the albumin buffer was $<50 / \mu \mathrm{val} / 1$. A constant flow rate of $1 \mathrm{ml} /$ min was achieved by a pressure of about $40 \mathrm{~mm} \mathrm{Hg}$. Glucose $(2.75$ or $8.25 \mathrm{mM}$ and $\mathrm{L}$-arginine-hydrochloride $(8.25 \mathrm{mM})$ dissolved in the perfusion medium were infused for different periods. Total effluent was collected at 1-2 min intervals after single passage through the pancreas and aliquots were immediately frozen and stored at $-20^{\circ} \mathrm{C}$ until the time of assay. All samples were assayed in one batch. Insulin (IMI) was measured immunologically [15]. A pork insulin standard curve was used, iodine ${ }^{125}$ was used as tracer. Glucagon (TMG) was determined by means of a dextran charcoal technique [11]. All samples were incubated for $48 \mathrm{~h}$ at $4^{\circ} \mathrm{C}$. Glucagon was labeled with $\mathrm{I}^{125}$. Our own, high affinity rabbit antibody was used in a final dilution of $1: 1000$. The stability of glucagon was ensured by adding 4000 units of Trasylol to $1 \mathrm{ml}$ perfusate; the degradation rate was found to be negligible as controlled by samples of exogenous glucagon.

Statistical evaluations were carried out using to the Student $t$ test. For all values the standard error of the mean is given (SEM).

\section{Results}

The diabetic animals exhibited a ++ glycosuria; fasting blood sugar levels ranged between 200-300 $\mathrm{mg} \%$. Corresponding levels of immunologically measurable insulin (IMI) were significantly elevated (1.20 土 $28 \mu \mathrm{u} / \mathrm{ml}$ ) compared to controls $(25 \pm 3 \mu \mathrm{u} / \mathrm{ml})$.

The perfusion of the isolated pancreas of lean litter mice with glucose $2.75 \mathrm{mM}$ did not show any marked insulin release. In obese diabetic mice, however, the non stimulated basal insulin release was significantly elevated (Fig. 1). 
Stimulation with glucose $8.25 \mathrm{mM}$ showed the well known pattern of multiphasic insulin release, while in diabetic mice insulin secretion was delayed and markedly enhanced.

Addition of arginine $8.25 \mathrm{mM}$ caused an acute rise of insulin release in lean controls but a delayed rise in $\mathrm{db} / \mathrm{db}$ mice, similar to the glucose-induced insulin release. In diabetic mice, however, the rise of insulin

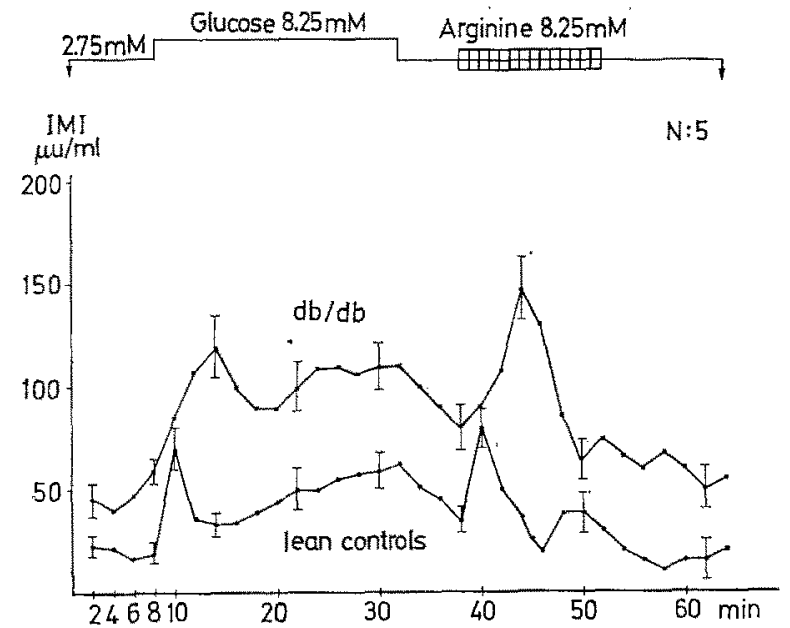

Fig. 1. Effects of glucose $(2.75$ and $8.25 \mathrm{mM})$ or arginine $(8.25 \mathrm{mM})$ and glucose $(2.75 \mathrm{mM})$ on insulin release of the isolated perfused pancreas of diabetic mice (Mean \pm SEM)

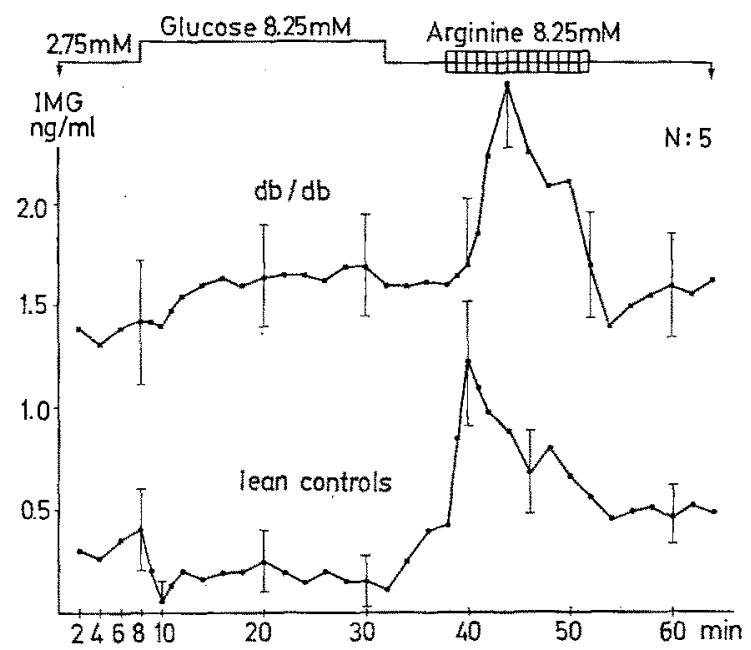

Fig. 2. Effects of glucose $(2.75 \mathrm{mM}$ and $8.25 \mathrm{mM})$ or arginine $8.25 \mathrm{mM}$ ) and glucose $(2.75 \mathrm{mM})$ on glucagon release of the isolated perfused panereas of diabetic mice (Mean \pm SEM)

was more pronounced. The arginine-induced insulin release could not be sustained, in both animal groups, over the total period of arginine infusion but fell back to a nadir within $6-8$ min.

At a glucose concentration of $2.75 \mathrm{mM}$ diabetic mice exhibited a pronounced hyperglucagonemia (1.5 $\mathrm{ng} / \mathrm{ml}$ ) compared to controls $(0.4 \mathrm{ng} / \mathrm{ml})$. Following glucose $8.25 \mathrm{mM}$, glucagon release was significantly depressed in $\mathrm{db}$-controls; in diabetio hyperinsulinemic mice, however, the glucagon release appeared nonsuppressible by glucose (Fig. 2).

The IMG response to arginine showed a prompt and marked elevation in control mice $(1.2 \mathrm{ng} / \mathrm{ml})$. In diabetic animals, this rise again was markedly exaggerated and exceeded. $2.4 \mathrm{ng} / \mathrm{ml}$ as peak level.

\section{Discussion}

It has been found previously $[15,16]$ and confirmed in the studies reported here, that diabetes mellitus is associated with hyperglucagonemia and an impaired suppression of alpha cell function by high glucose concentrations. This has been attributed mainly to the lack of insulin. The thesis was put forward that the alpha cell is an insulin requiring cell [17]. Samols, Tyler and Marks [21] even suggested a decreased suppressive effect of insulin upon glucagon secretion as the cause of hyperglucagonemia in diabetes mellitus. However, simple restoration of plasma insulin concentration did not fully restore the normal suppressibility of the alpha cell in genetically determined diabetics [26]. A near normal intrapancreatic insulin content in human diabetes did not prevent hyperglucagonemia. The lack of insulin per se, therefore, is unlikely to be the sole cause of hyperglucagonemia.

Already in 1952, Ferner [7] reported that the islets of Langerhans of certain diabetic subjects contained increased numbers of silver-positive cells which were believed to be alpha cells. In 1953, alpha cell hyperplasia was described in obese hyperglycemic mice [14] and high fasting glucagon levels were seen in obese children compared to normal controls [19]. Kalkhoff, Matute and Gossain [12] even described a relative hyperglucagonemia coexisting with hyperinsulinemia in nondiabetic obese states. No information, however, has been available about glucagon release in diabetes with hyperinsulinism. As shown in the present experi. ments, diabetic hyperinsulinemic mice appeared to have alpha cell function insensitive to hyperglycemia, while arginine induced an exaggerated rise in glucagon secretion. Simultaneously, there was an excessive and somewhat delayed hyperinsulinism, as previously deseribed [3] and similar to the obese, maturity onset human diabetic $(2,20)$.

Under normal conditions a negative feed back of insulin on glucagon release has been suggested [21]. In hyperinsulinaemic diabetes, however, one is confronted with an apparent contradiction. Glucagon secretion is markedly elevated and cannot be suppressed by excessive basal and reactive insulin release or high glucose levels. Rather there seems to be a non-suppressible glucagon release following high glucose levels, as first described in diabetic patients [16]. A stimulation of glucagon release by high glucose levels was also noted in the isolated perfused pancreas of streptozotocindiabetic rats [9]. 
Electron microscopic autoradiography of pancreatic islets in diabetic mice [4] revealed a maximum of labelled beta cells above $130 \mathrm{mg} \%$ blood glucose, but no labelled alpha cells. Severe hyperglycemia, however, correlated subsequently with a decline in beta cell DNA synthesis. This suggests, that increased alpha cell function may be only present when hyperinsulinism has already passed its maximum and decreased gradually due to an exhaustion of the B-cell function. This seems to be in accordance with observations by others [18], who inferred excessive glueagon synthesis from ultrastructural changes in ketotic and severely diabetic chinese hamsters.

A primary metabolic defect within the alpha cell was considered as one of several explanations for this phenomenon [26]. In addition hyperglucagonaemia might be due to a defect of the ventromedial nucleus of the hypothalamus in diabetic mice as described for hyperphagia and hyperinsulinism [5]. Hypophysectomy in dogs [6] and in rats [8] ultimately results in hyperplasia of alpha cells. In agreement with Samols et al. [21] it appears, however, more likely that the elevated pancreatic glucagon is primarily serving as a direct stimulus to insulin biosynthesis [22]. The secretion in the presence of inappropriate suppression of $\mathrm{A}$-cell function may be either due to primarily ineffective insulin or insulin antagonism.

Diabetic metabolism is associated with an inappropriate decrease of the molar ratio of insulin to glueagon [24]. Evaluation of this ratio with the perfused pancreas of mice at different glucose concentrations revealed marked changes from 1.1 at $2.75 \mathrm{mM}$ glucose to 7.5 at $8.25 \mathrm{mM}$ glucose in lean controls, similar to studies in rats [10], whereas diabetic mice exhibited only small changes from 0.9 at low glucose to 1.7 at high glucose levels.

\section{References}

1. Assan, R., Rosselin, G., Dolais, J.: Effets sur la glucagonémie des perfusions et ingestions d'acides aminées. J. Ann. Diabètol. Hôtel Dieu 7, 25 (1967)

2. Bagdade, J.D., Bierman, E. L., Porte, D. A.: The significance of basal insulin levels in the evaluation of the insulin response to glucose in diabetic subjects. J. clin. Invest. 46, 1549 (1967)

3. Cameron, D.P., Amherdt, M., Orei, L., Peyer, R., Stauffacher, W.: Biochemical and morphological studies of immunoreactive insulin secrotion in spontaneous and acquired obesity and/or hyperglycemia in rodents. Acta diabet. lat, 9, (suppl. 1), 89 (1972)

4. Chick., W.L., Like, A.A.: Studies in the diabetic mutant mouse III: Physiological factors associated with alterations in beta cell proliferation. Diabetologia 6, $243(1970)$

5. Coleman, D.L., Hummel, K.P.: The effects of hypothalamic lesions in genetically diabetic mice. Diabetologia $6,263(1970)$

6. Dorner, M., Stahl, J.: Recherches sur le glucagon II. Relation entre l'hypophyse antérieur et le système alpha-cellulaire du panoréas chez le chien. Rev. frang. Étud. clin. biol. 2, 118 (1957)
7. Ferner, H.: Das Inselsystem des Pankreas. Stuttgart: Georg Thieme 1952

8. Ferner, H., Tonutti, E.: Die Wirkung der Hypophysektomie auf das Zellbild der Inseln bei Ratten und Meerschweinchen. Z. Zellforsch. 38, 267 (1953)

9. Fussgänger, R.D.: Die Rolle des Glukagons bei der Zuckerkrankheit. Dtsch. Med. J.: 23, 601 (1972)

10. Fussgänger, R.D., Schröder, K.E., Goberna, R., Pfeiffer, E. F. Comparative studies on the mechanism of interxelated insulin and glucagon secretion. In prep. (1973)

11. Herbert, V.K., Lan, S., Gottlieb, C.W., Bleicher, S.J.: Coated charcoal immunoassay of insulin. J. elin. Endocr. 25, 1375 (1965)

12. Kalkhoff, R., Matute, M., Gossain, V.: Plasma glucagon in obesity. Clin. Res. 20, 802 (1972)

13. Katsilambros, N.Y., Abdel Rahman, Hinz, M., Fussgänger, R.D., Schröder, K.E., Straub, K., Pfeiffer, E.F.: Action of streptozotocin on insulin and glucagon responses of rat islets. Horm. Metab. Res. 2, 268 (1970)

14. Mayer, J., Andrus, S.B., Silides, D.J.: Effect of diethyldithiocarbamate and other agents on mice with obese-hyperglycemic syndrom. Endocrinology $\mathbf{5 3}, 572(1953)$

15. Melani, F., Ditschuneit, H., Bartelt, K., Friedrich, I., Pfeiffer, E.F.: Uber die radioimmunologische Bestimmung von Insulin im Blut. Klin. Wsehr. 43, 1000 $(1965)$

16. Müller, W.A., Faloona, G.R., Aguilar-Parada, E., Unger, R.H.: Abnormal alpha cell function in diabetes. Response to carbohydrate and protein ingestion. New Engl. J. Med. 283, 109 (1970)

17. Müller, W.A., Faloona, G.R., Unger, R.H. : Effect of experimental insulin deficiency on glucagon secretion. J. clin. Invest. 50, 1992 (1971)

18. Orci, L., Junod, A., Pictet, R., Renold, A., Rouiller, C.: Granulolysis in a cells of endocrine pancreas in spontaneous and experimental diabetes. J. Cell Biol. 38, 462 (1968)

19. Paulsen, E. P., Lawrence, A.M.: Glucagon hypersecretion in obese children. Lancet $1968 \mathrm{II}, 110$

20. Perley, M., Kipnis, D.M. : Plasma insulin response to glucose and tolbutamide of normal weight and obese diabetic subjects. Diabetes 15, 867 (1966)

21. Samols, E., Tyler, J.M., Marks, V.: Glucagon-insulin interrelationship. In: Glucagon, p. 151. Edited by Lefebvre, P.L. and Unger, R.H. Oxford: Pergamon Press 1972

22. Schatz, H., Hinz, M., V., Nierle, Chr., Pfeiffer, E.F.: Stimulation of ${ }^{3} \mathrm{H}$-Leucine incorporation into the proinsulin and insulin fraction of isolated pancreatic mouse islets. Diabetes, submitted and accepted 1973

23. Sussman, K. E., Vaughan, G.D., Timmer, R.F.: An in vitro method for studying insulin secretion in the perfused isolated rat pancreas. Metabolism 15, 466 (1966)

24. Unger, R.H.: Glucagon and the insulin: glucagon ratio in diabetes and other catabolic illnesses. Diabetes 20, 834 (1971)

25. Unger, R.H., Aguilar-Parada, E., Müller, W.A., Eisentraut, A.M.: Studies of pancreatic alpha cell function in normal and diabetic subjects. J. clin. Invest. 49, $837(1970)$

26. Unger, R. H., Madison, L.L., Müller, W.A. : Abnormal alpha cell function in diabetics. Diabetes 21, 301 (1972)

Dr. H. Laube

Zentrum für Innere Medizin

der Universität Ulm

79 Ulm/Donau

Steinhövelstr. 9 ,

Federal Republic of Germany 